\title{
Host genetic variants of ABCB1 and IL15 influence treatment outcome in paediatric acute lymphoblastic leukaemia
}

 \\ ${ }^{1}$ Division of Haematology-Oncology, Department of Paediatrics, Yong Loo Lin School of Medicine, National University Health \\ System, National University of Singapore, Singapore, Singapore; ${ }^{2}$ Department of Paediatrics, Faculty of Medicine, University of \\ Malaya, Kuala Lumpur, Malaysia; ${ }^{3}$ University of Malaya Cancer Research Institute, Faculty of Medicine, University of Malaya, \\ Kuala Lumpur, Malaysia; ${ }^{4}$ Department of Paediatric Oncology/Haematology, VU University Medical Center, Amsterdam, \\ The Netherlands; ${ }^{5}$ Department of Paediarics, Sime Darby Medical Centre Subang Jaya, Subang Jaya, Malaysia; ${ }^{6}$ Department of \\ Paediatric Medicine, Haematology/Oncology Service, KK Women's and Children's Hospital, Singapore, Singapore; \\ 'Viva-University Children's Cancer Centre, University Children's Medical Institute, National University Hospital, Singapore, \\ Singapore and ${ }^{8}$ National University Cancer Institute Singapore, National University Health System, Singapore
}

Background: Host germline variations and their potential prognostic importance is an emerging area of interest in paediatric ALL.

Methods: We investigated the associations between 20 germline variations and various clinical end points in 463 children with ALL.

Results: After adjusting for known prognostic factors, variants in two genes were found to be independently associated with poorer EFS: ABCB1 T/T at either 2677 (rs2032582) or 3435 (rs1045642) position ( $P=0.003$ ) and IL15 67276493G/G (rs17015014; $P=0.022)$. These variants showed a strong additive effect affecting outcome $(P<0.001)$, whereby patients with both risk genotypes had the worst EFS $(P=0.001)$, even after adjusting for MRD levels at the end of remission induction. The adverse effect of $A B C B 1$ $\mathrm{T} / \mathrm{T}$ genotypes was most pronounced in patients with favourable cytogenetics $(P=0.011)$ while the IL15 67276493G/G genotype mainly affected patients without common chromosomal abnormalities $(P=0.022)$. In both cytogenetic subgroups, increasing number of such risk genotypes still predicted worsening outcome $(P<0.001$ and $=0.009$, respectively).

Conclusion: These results point to the prognostic importance of host genetic variants, although the specific mechanisms remain unclarified. Inclusion of ABCB1 and IL15 variants may help improve risk assignment strategies in paediatric ALL.

The successful incorporation of risk-associated factors in contemporary treatment regimens has rendered paediatric acute lymphoblastic leukaemia (ALL) to be one of the most curable forms of cancer, with cure rates exceeding $80 \%$ in developed countries (Pui et al, 2011). Presenting parameters, such as age, leukocyte counts and cytogenetics are widely used (Schultz et al, 2007). In addition, early response to therapy measured by minimal residual disease (MRD) levels after initial remission induction therapy is an independent predictor of the eventual outcome and is increasingly used for risk assignment in many contemporary protocols (Pui et al, 2009; Conter et al, 2010; Yeoh et al, 2012).

Clinically, inter-patient variations in treatment response are seen even in the same leukaemia subtype. For instance, up to $28 \%$ of patients with poor prognosis $t(9 ; 22) / B C R-A B L 1$-positive ALL can be cured (Arico et al, 2000), whereas up to $15 \%$ of patients with good-prognosis $t(12 ; 21) / E T V 6-R U N X 1$ fusion or hyperdiploidy ( $>50$ chromosomes) relapse on a contemporary treatment protocol (Pui et al, 2009; Pui et al, 2011; Yeoh et al, 2012). 
Host-related factors may account for a significant proportion of inter-patient variation in treatment response and toxicity. The polymorphic thiopurine methyltransferase (TPMT) gene is a well-known example that affects 6-mercaptopurine (6-MP) metabolism (Relling et al, 1999; McLeod et al, 2000; Stanulla et al, 2005a), a drug widely used in treatment of ALL.

Paediatric ALL protocols use multi-drug combinations, which may be affected by polymorphisms participating in the transport, metabolism as well as detoxification of the individual drugs (Krajinovic et al, 2002; de Jonge et al, 2005; Rocha et al, 2005; Costea et al, 2006; Cunningham and Aplenc, 2007; Davidsen et al, 2008; Xu et al, 2012). However, the impact of such genomic variations on treatment outcome, especially in relation to conventional risk assignment strategies, remains to be fully elucidated. Using a candidate gene approach targeting 20 germline polymorphisms in 11 genes implicated in treatment response in paediatric ALL, we evaluated their influence on treatment outcome in 463 children enrolled in the Malaysia-Singapore ALL 2003 study. The selected candidates (Supplementary Table S1) have been reported either to influence the metabolism of the standard chemotherapy drugs used in treatment of ALL (e.g. MTHFR $677 \mathrm{C}>\mathrm{T}$ (de Jonge et al, 2005) and ABCB1 3435C > T (Jamroziak et al, 2004)) or affect MRD level at the end of induction (e.g. CCR5 246A > G (Davies et al, 2008) and IL15 SNPs (Yang et al, 2009)), or event-free survival (EFS, e.g. GSTM1 null (Rocha et al, 2005) and NQO1 609C > T (Krajinovic et al, 2002).

\section{MATERIALS AND METHODS}

Patients and samples. We studied a total of 463 consecutive patients who were enrolled from July 2002 to August 2009 (median follow-up of 5.7 years upon data analyses) in the MalaysiaSingapore (Ma-Spore) ALL 2003 study from four participating centers in Singapore and Malaysia (Yeoh et al, 2012). This smaller cohort has similar EFS (Supplementary Figure S1) as well as demographic composition (data not shown) compared with the entire Ma-Spore ALL patient group. Genotyping assays were carried out in patients who had sufficient DNA. The patients are primarily comprised of Chinese, Malays and Indians, according to self-reported ethnicity. The treatment protocol was a modification of the ALL IC-BFM 2002 backbone (Fronkova et al, 2008) with additional CCG-augmented BFM regimen for high-risk patients (Nachman et al, 1997). Risk assignment was based on clinical- and cytogenetic-presenting features as well as early response to therapy as determined by prednisolone response and molecular MRD at the end of remission induction and consolidation (Supplementary Table S2).

Mononuclear cells were separated and collected from bone marrow aspirates or peripheral blood at diagnosis and after remission, using a Ficoll-Paque (GE Healthcare, Little Chalfont, UK) density gradient centrifugation. DNA was isolated using TRIzol (Invitrogen, Carlsbad, CA, USA) according to the manufacturer's recommendation.

The study was approved by the local institutional review boards at all participating institutions and informed consent was obtained from patients or their parents in accordance with the Declaration of Helsinki.

Cytogenetic subgroup, MRD, and genotype. Morphological examination and immunophenotyping were performed in all patients. Karyotyping, DNA index, and oncogene fusion screening by reverse transcription PCR were performed in National University Hospital or KK Women's and Children's Hospital in Singapore. For the present study, $t(9 ; 22) / B C R-A B L 1$, $t(11 \mathrm{q} 23) / M L L$ rearrangements or hypodiploid ALL (modal chromosomes $<45$ or DNA index $<1.0$ ) were classified as unfavourable cytogenetic subgroup, while $t(12 ; 21) / E T V 6-R U N X 1$, $t(1: 19) / T C F-P B X 1$ or hyperdiploid ALL (modal chromosomes $>50$ or DNA index $\geqslant 1.16$ ) were classified as a favourable subgroup.

For MRD monitoring, patient-specific, leukaemia-associated markers targeting the $I g H, T C R \delta$, and $I g K-K d e$ rearrangements were quantitated using BIOMED-II primers and protocols (McClure et al, 2006; Fronkova et al, 2008), and results were interpreted according to the criteria of the EuroMRD Study Group (Pongers-Willemse et al, 1999; van der Velden et al, 2006).

GSTM1/T1 present/null and TYMS 28-bp enhancer repeat (rs34743033) were visualised on agarose gel directly after conventional PCR. Genotyping assays for other loci were performed using in-house allele-specific primer extension by real-time PCR. A qualified genotyping result must satisfy the following criteria: (a) at least one allele signal appears before the cycle threshold (CT) of 25; (b) for a homozygous call, CT difference between two allele signals exceeds four; and (c) for a heterozygous call, CT difference should be less than one. All bi-allelic loci studied were in Hardy-Weinberg equilibrium in each ethnic group (not applicable for GSTM1/T1 loci).

Statistical analyses. Homozygosity of the major allele in the single-nucleotide polymorphism (SNP) was used as the reference genotype unless otherwise specified. For each SNP, genotype was pooled as a dichotomous variable if applicable, and tested under both dominant and recessive models (1 degree of freedom). The grouping that yielded the smaller $P$-values was retained. To control for multiple testing while maintaining sufficient statistical power, we applied Benjamini-Hochberg Step-up FDR-controlling procedure for the results of preliminary test on individual SNP. Only the candidates with adjusted $P$-values of $\leqslant 0.05$ in multivariate tests were selected for further analyses. Subsequent investigation on the associations between shortlisted SNPs and various clinical end points was exploratory, where nominal $P$-values of $\leqslant 0.05$ were considered significant.

Patients who abandoned treatment for more than six continuous weeks were excluded from all analyses provided that no event occurred before the abandonment. The EFS and OS were estimated by both Kaplan-Meier ( $P_{\mathrm{KM}}$ by log rank test) and Cox regression ( $P_{\mathrm{COX}}$ by proportional hazards model) using PASW Statistics 18.0 (IBM, New York, NY, USA). The time-to-event was calculated from diagnosis until the occurrence of resistance (morphological blast count $\geqslant 5 \%$ at the end of remission induction), relapse (at any site), or death (from any cause), whichever occurred first, in EFS analysis $(N=74$; the time-to-event for resistance and induction death was registered as 1 day), or until death in OS analysis $(N=39)$. For patients in continuous complete remission (CCR), survival times were censored at the date of last follow-up or until 31 December 2012. Cumulative incidence of relapse (including resistance; $N=51$ ) was estimated in both univariate ( $P_{\mathrm{G}}$ by Gray's test) and multivariate analyses $\left(P_{\mathrm{FG}}\right.$ by Fine and Gray hazards model) using R (version 3.0.1) packages according to published guidelines (Scrucca et al, 2007, 2010), where death was considered as a competing event. Clinical-presenting features, that is, the race, sex, lineage, NCI risk group (the risk for infantile cases was set to 'high' in statistical analyses), and cytogenetic subgroup, were used as co-variables in all multivariate analyses. The genotypes were examined together with clinical features in a full model (that is, non-stepwise mode). The particular genotypes that were associated with poorer EFS (termed as risk genotypes) were also tested for their additive effect on EFS, with an increasing number of such risk genotypes. When appropriate, Day 33 (end-of-induction) MRD was further added in the regression model to test the robustness of significant results discovered.

To investigate potential sampling bias, patients enrolled were split into two halves according to the time of enrolment at each 
participating center, and the additive effect of risk genotypes was re-examined. In addition, as a validation we performed re-sampling to generate 100 test sets each comprising $50 \%$ of events and $50 \%$ of continuous complete remission randomly selected from the original cohort and evaluated the additive effect of risk genotypes in each set. In both scenarios, clinical co-variables were included in analyses.

Binary logistic regression was used to identify the genotypes associated with failure to achieve complete remission (that is, resistance or induction death; $N=30$ ) and treatment-related mortality (defined as the death during remission induction or in complete remission without prior leukemic relapse; $N=23$ ) after adjusting for clinical and cytogenetic features. The genotype frequencies in different categorical groups were compared by using the Pearson Chi-square test.

Haplotype frequencies of $A B C B 1$ and IL15 genes were calculated using Haploview (version 4.2) (Barrett et al, 2005).

\section{RESULTS}

Identification of polymorphisms of ABCB1 and IL15 as predictors of EFS. The clinical and cytogenetic features at presentation and the prevalence of alleles studied are summarised in Table 1, Supplementary Tables S3a and S3b, respectively. All bi-allelic loci were in Hardy-Weinberg equilibrium in each ethnic group (not applicable for GSTM1/T1 loci). Of the presenting features examined, unfavourable cytogenetics was associated with a significantly poorer EFS ( $P_{\mathrm{COX}}<0.001$; Table 2$)$, while NCI highrisk status had borderline significance $\left(P_{\mathrm{COX}}=0.091\right.$; Table 2$)$; selfreported ethnicity, gender, and cell type were not significantly related to EFS. The complete genotype data as well as patient characteristics are available for research purposes upon request.

Among the 20 polymorphisms examined individually in preliminary test, polymorphisms in ABCB1 (rs2032582 and rs1045642) and IL15 (rs17015014) were found eligible for further analyses (adjusted $P=0.038$ and 0.048 , respectively; Supplementary Table S4). They were subsequently analysed together in a Cox regression model adjusting for presenting clinical and cytogenetic features (Table 2). The homozygosity of either $A B C B 12677 \mathrm{~T} / \mathrm{T}$ or $3435 \mathrm{~T} / \mathrm{T}$ was still significantly related with a poorer EFS compared with other genotypes at these two loci $\left(P_{\mathrm{KM}}=0.001 ; \quad P_{\mathrm{COX}}=0.003, \quad \mathrm{HR}=2.11, \quad 95 \% \quad \mathrm{CI}=1.29-3.45\right.$; Figure 1A). There was moderate linkage disequilibrium (LD) between $2677 \mathrm{~T}$ and $3435 \mathrm{~T}$ (details shown in later section). IL15 $67276493 \mathrm{G} / \mathrm{G}$ was also associated with significantly poorer EFS compared with $67276493 \mathrm{G} / \mathrm{C}$ and $\mathrm{C} / \mathrm{C} \quad\left(P_{\mathrm{KM}}=0.050\right.$; $P_{\mathrm{COX}}=0.022, \mathrm{HR}=1.84,95 \% \mathrm{CI}=1.09-3.08$; Figure $\left.1 \mathrm{~B}\right)$. Adjusting for MRD at the end of remission induction (Supplementary Figures S2 A-B) or excluding the cases of resistance from EFS analyses (Supplementary Table S5 and Supplementary Figures $\mathrm{S} 3 \mathrm{~A}-\mathrm{B})$ did not alter the significance of these polymorphisms identified.

The risk genotypes, that is, $A B C B 1 \mathrm{~T} / \mathrm{T}$ at 2677 or 3435 or both as well as IL15 $67276493 \mathrm{G} / \mathrm{G}$, exhibited an additive effect $\left(P_{\mathrm{KM}}<0.001 ; \quad P_{\mathrm{COX}}<0.001, \quad \mathrm{HR}=1.97, \quad 95 \% \quad \mathrm{CI}=1.38-2.82\right)$ demonstrating progressively poorer EFS in patients with an increasing number of risk genotypes (Table 2 and Figure 1C). Compared with the patients without any risk genotype, the hazard of adverse events raised 2.2 folds in patients with one risk genotype $\left(P_{\mathrm{KM}}=0.005 ; P_{\mathrm{COX}}=0.003, \mathrm{HR}=2.20,95 \% \mathrm{CI}=1.30-3.70\right)$ and 3.6 folds in those with two risk genotypes $\left(P_{\mathrm{KM}}=0.002\right.$; $\left.P_{\mathrm{COX}}=0.001, \mathrm{HR}=3.64,95 \% \mathrm{CI}=1.68-7.92\right)$. After adjusting for MRD at the end of remission induction (Supplementary Table S6 and Supplementary Figure S2C) or excluding the cases of resistance (Supplementary Table S7 and Supplementary Figure $\mathrm{S} 3 \mathrm{C}$ ), this additive effect remained significant. There was no
Table 1. Distribution of patients according to demographic and prognostic categories

\begin{tabular}{l|r|}
\hline Clinical feature & Frequency (\%), \\
\hline Race & \\
\hline Chinese & $215(46.4)$ \\
Malays & $183(39.5)$ \\
Indians and others $^{\text {a }}$ & $65(14.0)$
\end{tabular}

Sex

\begin{tabular}{|l|l|}
\hline Male & $259(55.9)$ \\
Female & $204(44.1)$ \\
\hline
\end{tabular}

Age

\begin{tabular}{|l|r|}
\hline 1 to 10 years & $371(80.1)$ \\
\hline
\end{tabular}

Younger than 1 or older than 10 years

WBC

\begin{tabular}{l|c}
\hline Below $50 \times 10^{9} \mathrm{I}^{-1}$ & $343(74.1)$ \\
Over $50 \times 10^{9} \mathrm{I}^{-1}$ & $119(25.7)$ \\
Unknown $^{\mathbf{b}}$ & $1(0.2)$
\end{tabular}

Lineage

\begin{tabular}{|l|r|}
\hline B cell & $424(91.6)$
\end{tabular}

\begin{tabular}{l|r}
$T$ cell & $39(8.4)$
\end{tabular}

\section{$\mathrm{NCl}$ risk group}

\begin{tabular}{l|c}
\hline Standard & $291(62.9)$ \\
High $^{c}$ & $171(36.9)$ \\
Unknown $^{\text {b }}$ & $1(0.2)$
\end{tabular}

Cytogenetic subtype (B-ALL only)

Favourable

\begin{tabular}{|l|l}
\hline $\mathrm{t}(12 ; 21) / E T V 6-R U N X 1$ & $86(20.3)$
\end{tabular}

$\mathrm{t}(1 ; 19) /$ TCF3-PBX1 $22(5.2)$

Hyperdiploidy

84 (19.8)

\section{Unfavourable}

$\mathrm{t}(9 ; 22) / B C R-A B L 1$

$\mathrm{t}(11 \mathrm{q} 23) / M L L$ rearrangements

Hypodiploidy

Others $^{d}$

Unknown ${ }^{\text {b }}$

19 (4.5)

14 (3.3)

5 (1.2)

$191(45.0)$

$3(0.7)$

Day 33 (end-of-induction) MRD

\begin{tabular}{l|c}
\hline Less than $10^{-4}$ & $188(40.6)$ \\
$10^{-4}$ to $10^{-2}$ & $174(37.6)$ \\
More than $10^{-2}$ & $41(8.9)$ \\
Unknown & $60(13.0)$
\end{tabular}

Outcome (the 1st event occured)

\begin{tabular}{|l|l}
\hline CCR & $368(79.5)$
\end{tabular}

Abscondment $^{\mathrm{e}} \quad 21(4.5)$

Resistance 20 (4.3)

\begin{tabular}{l|l} 
Relapse (any site) after CR & 31 (6.7)
\end{tabular}

Treatment-related mortality

\begin{tabular}{|l|l}
\hline During induction & $10(2.2)$
\end{tabular}

\begin{tabular}{l|r} 
After CR & $13(2.8)$
\end{tabular}

Abbreviations: $\quad C C R=$ continuous $\quad$ complete remission; $\quad C R=$ complete remission $\mathrm{MRD}=$ minimal residual disease.

${ }^{a^{\prime}}$ Others' refer to a few of Caucasian, Vietnamese, Indonesian, and Philippines.

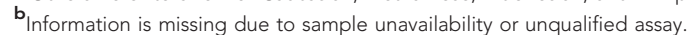

'The risk for infantile cases was set to 'high' in statistical analyses.

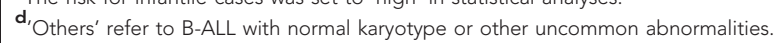

${ }^{\mathbf{e}}$ Patients who abandoned treatment for more than six continuous weeks. 
significant EFS difference between patients with only $A B C B 1$ risk genotype and those with only IL15 risk genotype (data not shown).

To further investigate the impact of $A B C B 12677 \mathrm{G}>\mathrm{T} / \mathrm{A} /$ $3435 \mathrm{C}>\mathrm{T}$ and IL15 67276493G $>\mathrm{C}$ genotypes on a specific event, we examined their influence on the cumulative incidence of relapse

\begin{tabular}{|c|c|c|}
\hline Variable & $\mathrm{HR}(95 \% \mathrm{Cl})$ & $\boldsymbol{P}$-value \\
\hline \multicolumn{3}{|l|}{$\mathrm{NCl}$ risk group } \\
\hline $\begin{array}{l}\text { Standard } \\
\text { High }\end{array}$ & $\begin{array}{c}\text { Ref. } \\
1.56(0.93-2.60)\end{array}$ & 0.091 \\
\hline Cytogenetic subgroup & & $<0.001$ \\
\hline $\begin{array}{l}\text { Favourable } \\
\text { Others } \\
\text { Unfavourable }\end{array}$ & $\begin{array}{c}\text { Ref. } \\
2.10(1.13-3.89) \\
6.48(3.09-13.57)\end{array}$ & $\begin{array}{r}0.018 \\
<0.001\end{array}$ \\
\hline
\end{tabular}

$A B C B 1,2677 G>T / A(r s 2032582)$ and $3435 C>T$ (rs1045642)

\begin{tabular}{|l|c|c|}
\hline $\begin{array}{l}\text { Other genotypes } \\
2677 \mathrm{~T} / \mathrm{T} \text { or } 3435 \mathrm{~T} / \mathrm{T} \text { or both }\end{array}$ & $\begin{array}{c}\text { Ref. } \\
2.11(1.29-3.45)\end{array}$ & 0.003 \\
\hline
\end{tabular}

\section{IL15, 67276493G $>$ C (rs17015014)}

\begin{tabular}{|c|c|c|}
\hline $\begin{array}{l}\mathrm{G} / \mathrm{C} \text { and } \mathrm{C} / \mathrm{C} \\
\mathrm{G} / \mathrm{G}\end{array}$ & $\begin{array}{c}\text { Ref. } \\
1.84(1.09-3.08)\end{array}$ & 0.022 \\
\hline \multicolumn{3}{|l|}{$\mathrm{NCl}$ risk group } \\
\hline $\begin{array}{l}\text { Standard } \\
\text { High }\end{array}$ & $\begin{array}{c}\text { Ref. } \\
1.56(0.93-2.60)\end{array}$ & 0.090 \\
\hline Cytogenetic subgroup & & $<0.001$ \\
\hline $\begin{array}{l}\text { Favourable } \\
\text { Others } \\
\text { Unfavourable }\end{array}$ & $\begin{array}{l}\text { Ref. } \\
2.12(1.14-3.92) \\
6.61(3.18-13.74)\end{array}$ & $\begin{array}{r}0.017 \\
<0.001\end{array}$ \\
\hline The number of risk genotypes ${ }^{a}$ & & 0.001 \\
\hline $\begin{array}{l}0 \\
1 \\
2 \\
\text { Additive effect }\end{array}$ & $\begin{array}{c}\text { Ref. } \\
2.20(1.30-3.70) \\
3.64(1.68-7.92) \\
1.97(1.38-2.82)\end{array}$ & $\begin{array}{r}0.003 \\
0.001 \\
<0.001\end{array}$ \\
\hline
\end{tabular}

Abbreviations: $\mathrm{Cl}=$ confidence interval; $\mathrm{HR}=$ hazards ratio. Regression was adjusted for patients' race, sex, lineage, $\mathrm{NCl}$ risk group, and cytogenetic subgroup. Only variables with nominal $P$ of $<0.1$ are shown in the table. A total of 413 cases with complete information were eligible for this analysis.

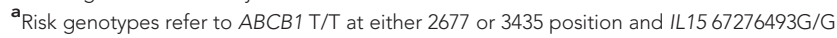

(including resistance), failure to achieve complete remission as well as treatment-related mortality. Homozygosity of either $A B C B 1$ $2677 \mathrm{~T} / \mathrm{T}$ or $3435 \mathrm{~T} / \mathrm{T}$ significantly increased the risk of relapse in both univariate $\left(P_{\mathrm{G}}=0.001\right.$; Supplementary Figure $\left.\mathrm{S} 4 \mathrm{~A}\right)$ and multivariate models after adjusting for clinical and cytogenetic features $\quad\left(P_{\mathrm{FG}}=0.011, \quad \mathrm{HR}=2.17, \quad 95 \% \quad \mathrm{CI}=1.19-3.94\right.$; Supplementary Table S8). The risk of relapse in patients with at least one $\mathrm{T} / \mathrm{T}$ was $20.4 \%$ compared with $9.0 \%$ in those without any $\mathrm{T} / \mathrm{T}$. Taking the end-of-induction MRD level into account did not alter the significance $\left(P_{\mathrm{FG}}=0.027, \mathrm{HR}=2.01,95 \%\right.$ $\mathrm{CI}=1.08-3.73)$. The risk of relapse also became higher with increasing number of risk genotypes $\left(P_{\mathrm{G}}<0.001\right.$; Supplementary Figure S4B; $\quad P_{\mathrm{FG}}=0.011, \quad \mathrm{HR}=1.84, \quad 95 \% \quad \mathrm{CI}=1.15-2.93$; Supplementary Table S8). The trend remained significant after adjusting for the end-of-induction $\mathrm{MRD}$ level $\left(P_{\mathrm{FG}}=0.026\right.$, $\mathrm{HR}=1.69,95 \% \mathrm{CI}=1.07-2.68$ ).

IL15 $67276493 \mathrm{G} / \mathrm{G}$ was associated with higher risk of failure to achieve complete remission when compared with $\mathrm{G} / \mathrm{C}$ and $\mathrm{C} / \mathrm{C}$ genotypes $\quad(P=0.009, \quad \mathrm{OR}=3.14, \quad 95 \% \quad \mathrm{CI}=1.34-7.36$; Supplementary Table S9). G/G homozygosity also correlated with poorer overall survival $\left(P_{\mathrm{KM}}=0.050 ; P_{\mathrm{COX}}=0.005, \mathrm{HR}=2.74\right.$, $95 \% \mathrm{CI}=1.35-5.58$; Supplementary Table S10 and Supplementary Figure S5), primarily due to more than 3-fold higher risk of treatment-related mortality in patients with IL15 67276493G/G $(P=0.015, \mathrm{OR}=3.40,95 \% \mathrm{CI}=1.27-9.11$; Supplementary Table S11).

We also examined the associations of identified risk genotypes with known risk factors. Neither T/T homozygosity at $A B C B 1$ 2677 or 3435 nor IL15 67276493G/G was found to correlate with cytogenetics and MRD level after remission induction (Supplementary Table S12).

Prognostic significance of $\mathrm{ABCB} 1$ and IL15 in patient subgroups. In patients with favourable cytogenetics, $\mathrm{T} / \mathrm{T}$ homozygosity at either $A B C B 12677$ or 3435 position was associated with a significantly poorer EFS $\left(P_{\mathrm{KM}}=0.011 ; P_{\mathrm{COX}}=0.011\right.$, $\mathrm{HR}=4.02,95 \% \mathrm{CI}=1.38-11.75$; Figure $2 \mathrm{~A})$. The EFS in patients carrying $A B C B 12677 \mathrm{~T} / \mathrm{T}$ or $3435 \mathrm{~T} / \mathrm{T}$ was $78.2 \% \pm 7.6 \%$, compared with $94.4 \% \pm 1.9 \%$ in those carrying other genotypes. Such an association became even stronger after adjusting for MRD level $\left(P_{\mathrm{COX}}<0.001, \mathrm{HR}=19.26,95 \% \mathrm{CI}=4.43-83.72 ; 80.6 \% \pm 8.6 \%\right.$ vs $98.9 \% \pm 0.8 \%)$. In contrast, the impact of IL15 67276493 genotype was more pronounced in patients who do not carry chromosomal abnormalities of known prognosis, showing a significantly worse EFS in $\mathrm{G} / \mathrm{G}$ carriers than the others $\left(P_{\mathrm{KM}}=0.038 ; P_{\mathrm{COX}}=0.022\right.$, $\mathrm{HR}=2.20, \quad 95 \% \quad \mathrm{CI}=1.12-4.30$; Figure $2 \mathrm{C})$, with $\mathrm{EFS}$ of $73.9 \% \pm 5.6 \%$ for $\mathrm{G} / \mathrm{G}$ carriers and $86.7 \% \pm 2.8 \%$ for $\mathrm{G} / \mathrm{C}$ and $\mathrm{C} / \mathrm{C}$ carriers, respectively. Adjustment for MRD level did not
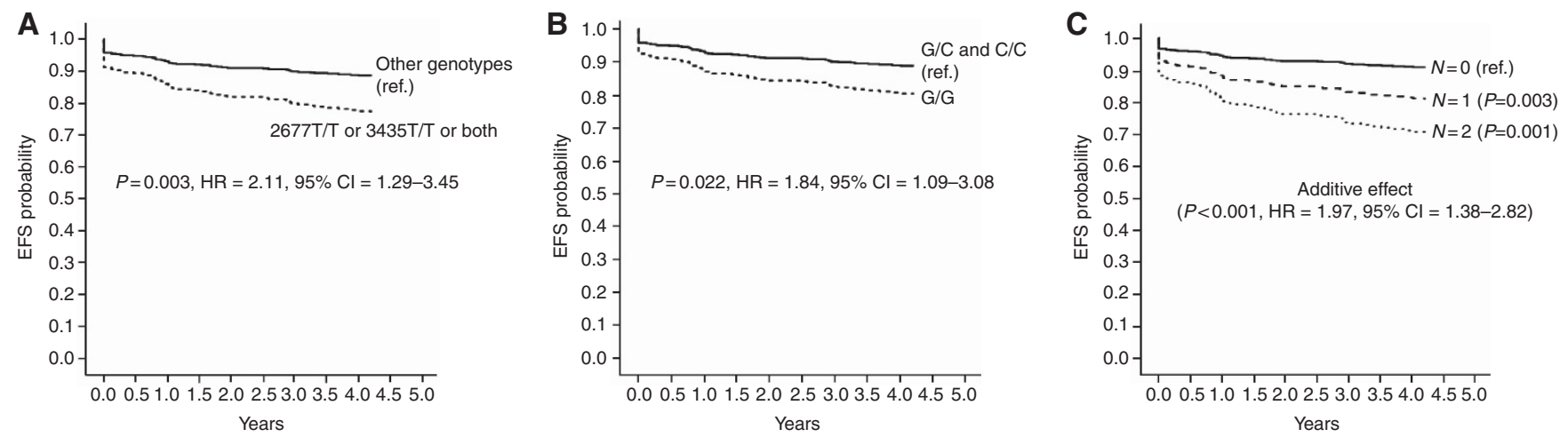

Figure 1. Plots of EFS probability for 413 patients enrolled in the Malaysia-Singapore ALL 2003 Study. Regression was adjusted for patients' race, sex, lineage, $\mathrm{NCl}$ risk group, and cytogenetic subgroup. The patients were stratified by respective genotypes of (A) ABCB1 2677G > T/A/ 3435 C > T, (B) IL15 67276493G > C, and by (C) the number of risk genotypes. 

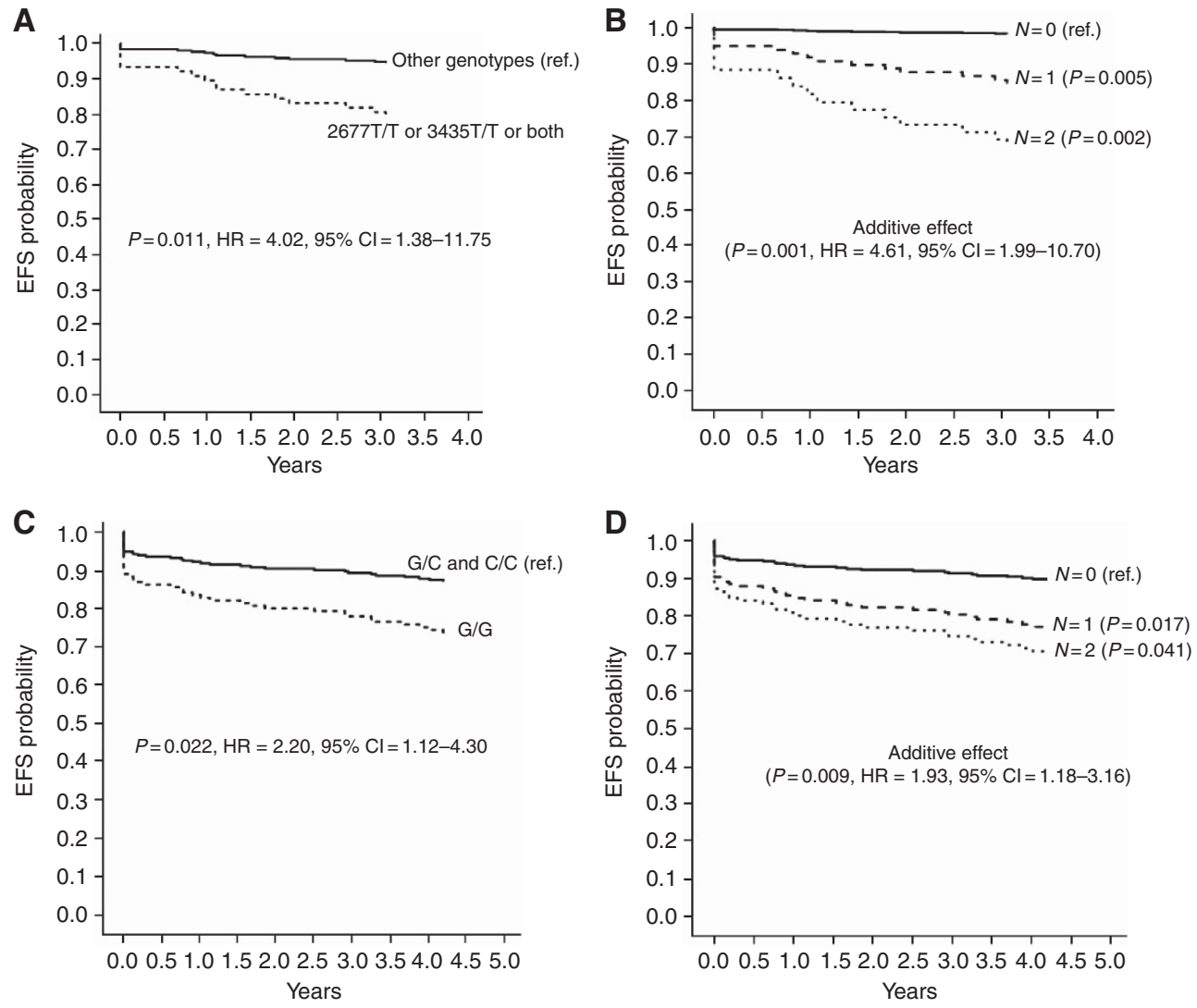

Figure 2. Plots of EFS probability for patients without high-risk cytogenetic lesions. Regression was adjusted for patients' race, sex, lineage, and $\mathrm{NCl}$ risk group. The patients were stratified by $(\mathbf{A}) \mathrm{ABCB} 12677 \mathrm{G}>\mathrm{T} / \mathrm{A} / 3435 \mathrm{C}>\mathrm{T}(\mathrm{N}=184)$ and $(\mathrm{B})$ the number of risk genotypes $(\mathrm{N}=174)$ in favourable cytogenetic subgroup, and (C) IL15 67276493G >C (N=209) and (D) the number of risk genotypes in the subgroup without common chromosomal abnormalities ( $N=208)$.

moderate the significance $\left(P_{\mathrm{COX}}=0.022, \quad \mathrm{HR}=2.30, \quad 95 \%\right.$ $\mathrm{CI}=1.13-4.70 ; 78.6 \% \pm 5.4 \%$ vs $90.2 \% \pm 2.7 \%)$.

In both cytogenetic subgroups, the additive effect of risk genotypes was found $\left(P_{\mathrm{KM}}<0.001\right.$ and $P_{\mathrm{COX}}<0.001$, Figure $2 \mathrm{~B}$; and $P_{\mathrm{KM}}=0.013$ and $P_{\mathrm{COX}}=0.009$, Figure $\left.2 \mathrm{D}\right)$ and remained significant after adjusting for MRD level $\left(P_{\mathrm{COX}}<0.001\right.$ and $=0.008$ respectively). In addition, we also examined the influence of risk genotypes in the two major ethnic groups, the Chinese and Malays, respectively. In both races, the additive effect of risk genotypes was also found $\left(P_{\mathrm{KM}}<0.001\right.$ and $P_{\mathrm{COX}}=0.001$ in the Chinese, Supplementary Figure S6A; $P_{\mathrm{KM}}=0.075$ and $P_{\mathrm{COX}}=0.036$ in the Malays, Supplementary Figure S6B) and remained significant after adjusting for MRD level ( $P_{\mathrm{COX}}=0.003$ and $=0.006$, respectively).

Validation tests. Patients were split into two halves based on the time of enrolment at each participating centre. In both cohorts, the additive effect of T/T homozygosity at $A B C B 12677$ or 3435 and IL15 67276493G/G still remained significant (Supplementary Figure S7A, C), even after adjusting for MRD levels at the end of induction (Supplementary Figure S7B, D). In addition, we generated 100 random test sets by re-sampling. Of these 100 test scenarios, the significance was achieved for 86 test sets (Supplementary Figure S8A), and all results consistently showed that increasing number of risk genotypes corresponded to a poorer EFS (i.e., HR > 1; Supplementary Figure S8B).

Linkage disequilibrium. As multiple loci in $A B C B 1$ and $I L 15$ were genotyped, we calculated the linkage disequilibrium (LD) among different alleles. Two loci, $A B C B 12677$ (rs2032582) and $A B C B 1$ 3435 (rs1045642), were in a moderate LD block. The LD was slightly stronger in the Chinese $\left(r^{2}=0.58\right.$ for entire patient cohort and $r^{2}=0.74$ for the Chinese; Supplementary Figure S9), with two major haplotypes, 2677G-3435C (52.3\%) and 2677T-3435T (36.2\%). IL15 67276493G $>$ C (rs17015014) was not in LD with any other studied loci of the IL15 gene (Supplementary Figure S10).

\section{DISCUSSION}

In childhood ALL, there is significant inter-individual variation in response to chemotherapy, which is not fully predicted by presenting features such as age and leukaemic cytogenetics. Newly described markers such as IKZF1 and CRLF2 have demonstrated prognostic impact in many studies (Mullighan et al, 2009; Buitenkamp et al, 2012; Chen et al, 2012; Feng and Tang, 2013), but their values still remain inconclusive in the Malaysia-Singapore ALL 2003 study according to our pilot investigations (data not shown). Here we showed that host germline variants of $A B C B 1$ and IL15 genes are significant predictors of treatment outcome, suggesting that the characterisation of these genes' variants at diagnosis could contribute to risk-stratification strategies. In our study, the $A B C B 12677 \mathrm{~T} / \mathrm{T}$ or $3435 \mathrm{~T} / \mathrm{T}$ genotypes were associated with an increased risk of relapse/resistance. $A B C B 1$ $2677 \mathrm{G}>\mathrm{T} / \mathrm{A}$ introduces an Ala-to-Ser/Thr change in exon 21 while $3435 \mathrm{C}>\mathrm{T}$ is a synonymous polymorphism in exon 26 , which affects transport by altering substrate specificity (Kimchi-Sarfaty et al, 2007). Various studies have shown that not all synonymous SNPs are considered silent; they can cause changes in protein expression, conformation or function and are increasingly 
implicated in human disease risk and other complex traits (Sauna and Kimchi-Sarfaty, 2011).

Large studies in patients with acute myocardial infarction on oral anti-coagulant clopidogrel, a substrate of P-glycoprotein (P-gp), reported lower drug levels and poorer cardiovascular outcomes in patients with $A B C B 13435 \mathrm{~T} / \mathrm{T}$ homozygotes (Simon et al, 2009; Mega et al, 2010). Oral dexamethasone, used extensively in paediatric ALL treatment including our Ma-Spore ALL 2003 protocol, is also a known substrate for P-gp. Patients with $A B C B 12677 \mathrm{~T} / \mathrm{T}$ or $3435 \mathrm{~T} / \mathrm{T}$ may have lower systemic dexamethasone exposure due to higher $A B C B 1$ expression on the apical villi of enterocytes (Nakamura et al, 2002), causing enhanced extrusion of drugs into the intestinal lumen. Supporting this hypothesis, Yang et al (2012) recently reported two $A B C B 1$ variants (rs10264856 and rs4728709) that affected oral dexamethasone clearance and were associated with increased risk of relapse in the St Jude and COG cohorts, although we did not observe any LD between rs10264856/rs4728709 and rs2032582/rs1045642 in our study as well as the data from 1000 Genomes Project (the maximum $r^{2}$ is only 0.14 ). Taken together with our findings on $A B C B 12677$ and 3435, these strongly suggest the importance of $A B C B 1$ variants in treatment of childhood ALL.

However, Jamroziak et al (2004) and Stanulla et al (2005b) previously reported lower EFS $(N=111)$ and higher CNS relapse $(N=34)$, respectively, in $A B C B 13435 \mathrm{C} / \mathrm{C}$ carriers treated on the BFM-ALL 86/90/95 protocols. Differences in the type of steroid used during induction therapy (prednisolone in the BFM-ALL $86 / 90 / 95$ compared with dexamethasone in Ma-Spore ALL 2003) may account for this observed difference. In addition, the lower frequency of $A B C B 12677 \mathrm{~T}$ and $3435 \mathrm{~T}$ alleles among African Americans (10.0\% and 20.2\%, respectively) (Kroetz et al, 2003) compared with our studied population $(43.6 \%$ and $40.5 \%$, respectively) may mask the effect of $A B C B 1$ variants on treatment outcome in the previously reported St Jude Total XIIIB protocol (Rocha et al, 2005).

The manner that $A B C B 1$ variants affect the $\mathrm{P}$-gp expression on the apical villi of enterocytes remains unresolved (Lin and Yamazaki, 2003; Leschziner et al, 2007; Hodges et al, 2011; Wolf et al, 2011). Nakamura et al (2002) reported that healthy Japanese subjects with $3435 \mathrm{~T} / \mathrm{T}$ had significantly higher duodenal $A B C B 1$ mRNA expression and lower digoxin plasma level compared with $\mathrm{C} / \mathrm{C}$ or $\mathrm{C} / \mathrm{T}$ genotype carriers, while Hoffmeyer et al (2000) and Efferth et al (2003) disagreed with such a correlation. The effect of $A B C B 1$ polymorphisms on P-gp activity is likely dependent on the substrates as well as the tissues (or cell types) studied, thus becoming a confounding factor when studying P-gp genotypephenotype relationship. Further studies in correlating dexamethasone clearance and $A B C B 1$ polymorphisms are required.

Considering the drug efflux capacity of P-gp, it is rational to speculate that the impact of $A B C B 1$ genotype on the risk of relapse/ resistance originates from its effect on MRD level. Although not statistically significant in our patients, Day 33 MRD high risk (i.e., $\geqslant 10^{-2}$ ) tended to be enriched in the $A B C B 1 \mathrm{~T} / \mathrm{T}$ group compared with the others ( $14.9 \%$ vs $8.8 \%, P=0.088$, Supplementary Table S12). Published data on the relationship between $A B C B 1$ gene and MRD are controversial. For instance, an earlier report showed that the median $A B C B 1$ expression at diagnosis of childhood ALL were roughly comparable between the MRD-positive group and MRD-negative group at the end of induction therapy (Fedasenka et al, 2008). This finding was challenged by a very recent study reporting that mRNA expression of $A B C B 1$ higher than a certain cutoff would raise the risk of MRD positivity by 12 -fold after 1 -year treatment in children with ALL (Rahgozar et al, 2014). Such discrepancies are likely due to (but not limited to) the diverse grouping criteria, the quantitation methods applied, the time points investigated, and sampled populations in different studies. As the determinants on early treatment response are known to be multifactorial, a clear correlation between $A B C B 1$ genotype and MRD level may not be expected.

The IL15 67276493G/G genotype was associated with a poorer EFS and OS in our study, and carried a higher probability of treatment-related mortality. IL15 regulates T- and natural killer cell activation and proliferation, having central roles in cellmediated immunity against microbes (Yoshikai and Nishimura, 2000). Administration of exogenous IL15 in animal models causes severe but reversible neutropenia due to redistribution of neutrophils out of the circulation (Berger et al, 2009; Waldmann et al, 2011). This SNP resides in the $3^{\prime} \mathrm{UTR}$ region of the gene, which exerts a negative regulatory effect on the expression of IL15; polymorphism at the $3^{\prime} \mathrm{UTR}$ may reduce this negative regulation, resulting in an enhanced expression. It is noteworthy that genetic variants in IL15, albeit different IL15 SNPs, have been previously inferred to significantly correlate with the MRD level at the end of induction (Yang et al, 2009), a strong surrogate marker to predict treatment outcome.

ABCB1 3435T/T or 2677T/T and IL15 67276493G/G showed a surprising additive effect in predicting a poorer EFS probability, even after adjusting for MRD levels at the end of remission induction. P-glycoprotein mediates in transmembrane transport of cytokines. It has been reported that $A B C B 12677 \mathrm{~T} / \mathrm{T}-3435 \mathrm{~T} / \mathrm{T}$ are associated with lower secretion of cytokines in PHA-stimulated lymphocytes (Pawlik et al, 2005). Conversely, in HIV-infected individuals, P-glycoprotein expression and function are decreased and restored only after IL15 stimulation (Chang et al, 2000). Therefore, we speculate that $A B C B 12677 \mathrm{~T} / \mathrm{T}$ or $3435 \mathrm{~T} / \mathrm{T}$ may alter secretion of IL15, which affects cellular immune responses and treatment outcome consequently.

In summary, host genetic variations in $A B C B 1$ and IL15 genes influence treatment outcomes in paediatric ALL in this predominantly Asian population treated on the Ma-Spore ALL 2003. Inclusion of host variants in $A B C B 1$ and IL15 genes may help future risk assignment strategies and deserves further study in other treatment cohorts.

\section{ACKNOWLEDGEMENTS}

We thank Dr Chan Yiong Huak for guidance with statistical analysis and Professor Dario Campana for advice. We thank laboratory staff for helping out in the genotyping assays, as well as the patients and their families for their participation in the Ma-Spore ALL 2003 study. This work was supported by NMRC/ CSA/003/2008 and NMRC Centre Grant (2010), Children's Cancer Foundation (Singapore) and Viva Foundation for Children with Cancer. Leukaemia cell bank was supported by Cancer Science Institute, Singapore.

\section{CONFLICT OF INTEREST}

The authors declare no conflict of interest.

\section{AUTHOR CONTRIBUTIONS}

YL performed the data analyses; SKYK initiated the study and coordinated genotyping assays; HA coordinated the Ma-Spore ALL 2003 study at University of Malaya Cancer Research Institute, Faculty of Medicine, University of Malaya, Kuala Lumpur, Malaysia; AMIO performed genotyping assays; HPL coordinated the Ma-Spore ALL 2003 study at Sime Darby Medical Centre, Subang Jaya, Malaysia; AMT coordinated the Ma-Spore ALL 2003 study at KK Women's and Children's Hospital, Singapore; TCQ 
coordinated the Ma-Spore ALL 2003 study at National University Hospital, Singapore; AEJY, initiated the study, performed analyses, and wrote the manuscript with YL and SKYK and the input of all other authors.

\section{REFERENCES}

Arico M, Valsecchi MG, Camitta B, Schrappe M, Chessells J, Baruchel A, Gaynon P, Silverman L, Janka-Schaub G, Kamps W, Pui CH, Masera G (2000) Outcome of treatment in children with Philadelphia chromosomepositive acute lymphoblastic leukemia. $N$ Engl J Med 342: 998-1006.

Barrett JC, Fry B, Maller J, Daly MJ (2005) Haploview: analysis and visualization of LD and haplotype maps. Bioinformatics 21: 263-265.

Berger C, Berger M, Hackman RC, Gough M, Elliott C, Jensen MC, Riddell SR (2009) Safety and immunologic effects of IL-15 administration in nonhuman primates. Blood 114: 2417-2426.

Buitenkamp TD, Pieters R, Gallimore NE, van der Veer A, Meijerink JP, Beverloo HB, Zimmermann M, de Haas V, Richards SM, Vora AJ, Mitchell CD, Russell LJ, Schwab C, Harrison CJ, Moorman AV, van den Heuvel-Eibrink MM, den Boer ML, Zwaan CM (2012) Outcome in children with Down's syndrome and acute lymphoblastic leukemia: role of IKZF1 deletions and CRLF2 aberrations. Leukemia 26: 2204-2211.

Chang KH, Kim JM, Yoo NC, Kim WH, Park JH, Choi IH, Kim HS, Lee KW, Song YG, Hong SK, Kim HY (2000) Restoration of P-glycoprotein function is involved in the increase of natural killer activity with exogenous interleukin-15 in human immunodeficiency virus-infected individuals. Yonsei Med J 41: 600-606.

Chen IM, Harvey RC, Mullighan CG, Gastier-Foster J, Wharton W, Kang H, Borowitz MJ, Camitta BM, Carroll AJ, Devidas M, Pullen DJ, Payne-Turner D, Tasian SK, Reshmi S, Cottrell CE, Reaman GH, Bowman WP, Carroll WL, Loh ML, Winick NJ, Hunger SP, Willman CL (2012) Outcome modeling with CRLF2, IKZF1, JAK, and minimal residual disease in pediatric acute lymphoblastic leukemia: a Children's Oncology Group study. Blood 119: 3512-3522.

Conter V, Bartram CR, Valsecchi MG, Schrauder A, Panzer-Grumayer R, Moricke A, Arico M, Zimmermann M, Mann G, De Rossi G, Stanulla M, Locatelli F, Basso G, Niggli F, Barisone E, Henze G, Ludwig WD, Haas OA, Cazzaniga G, Koehler R, Silvestri D, Bradtke J, Parasole R, Beier R, van Dongen JJ, Biondi A, Schrappe M (2010) Molecular response to treatment redefines all prognostic factors in children and adolescents with B-cell precursor acute lymphoblastic leukemia: results in 3184 patients of the AIEOP-BFM ALL 2000 study. Blood 115: 3206-3214.

Costea I, Moghrabi A, Laverdiere C, Graziani A, Krajinovic M (2006) Folate cycle gene variants and chemotherapy toxicity in pediatric patients with acute lymphoblastic leukemia. Haematologica 91: 1113-1116.

Cunningham L, Aplenc R (2007) Pharmacogenetics of acute lymphoblastic leukemia treatment response. Expert Opin Pharmacother 8: 2519-2531.

Davidsen ML, Dalhoff K, Schmiegelow K (2008) Pharmacogenetics influence treatment efficacy in childhood acute lymphoblastic leukemia. J Pediatr Hematol Oncol 30: 831-849.

Davies SM, Borowitz MJ, Rosner GL, Ritz K, Devidas M, Winick N, Martin PL, Bowman P, Elliott J, Willman C, Das S, Cook EH, Relling MV (2008) Pharmacogenetics of minimal residual disease response in children with B-precursor acute lymphoblastic leukemia: a report from the Children's Oncology Group. Blood 111: 2984-2990.

de Jonge R, Hooijberg JH, van Zelst BD, Jansen G, van Zantwijk CH, Kaspers GJ, Peters GJ, Ravindranath Y, Pieters R, Lindemans J (2005) Effect of polymorphisms in folate-related genes on in vitro methotrexate sensitivity in pediatric acute lymphoblastic leukemia. Blood 106: 717-720.

Efferth T, Sauerbrey A, Steinbach D, Gebhart E, Drexler HG, Miyachi H, Chitambar CR, Becker CM, Zintl F, Humeny A (2003) Analysis of single nucleotide polymorphism C3435T of the multidrug resistance gene MDR1 in acute lymphoblastic leukemia. Int J Oncol 23: 509-517.

Fedasenka UU, Shman TV, Savitski VP, Belevcev MV (2008) Expression of MDR1, LRP, BCRP and Bcl-2 genes at diagnosis of childhood all: comparison with MRD status after induction therapy. Exp Oncol 30: 248-252.

Feng J, Tang Y (2013) Prognostic significance of IKZF1 alteration status in pediatric B-lineage acute lymphoblastic leukemia: a meta-analysis. Leuk Lymphoma 54: 889-891.

Fronkova E, Mejstrikova E, Avigad S, Chik KW, Castillo L, Manor S, Reznickova L, Valova T, Zdrahalova K, Hrusak O, Jabali Y, Schrappe M,
Conter V, Izraeli S, Li CK, Stark B, Stary J, Trka J (2008) Minimal residual disease (MRD) analysis in the non-MRD-based ALL IC-BFM 2002 protocol for childhood ALL: is it possible to avoid MRD testing? Leukemia 22: 989-997.

Hodges LM, Markova SM, Chinn LW, Gow JM, Kroetz DL, Klein TE, Altman RB (2011) Very important pharmacogene summary: ABCB1 (MDR1, P-glycoprotein). Pharmacogenet Genomics 21: 152-161.

Hoffmeyer S, Burk O, von Richter O, Arnold HP, Brockmoller J, Johne A, Cascorbi I, Gerloff T, Roots I, Eichelbaum M, Brinkmann U (2000) Functional polymorphisms of the human multidrug-resistance gene: multiple sequence variations and correlation of one allele with P-glycoprotein expression and activity in vivo. Proc Natl Acad Sci USA 97: 3473-3478.

Jamroziak K, Mlynarski W, Balcerczak E, Mistygacz M, Trelinska J, Mirowski M, Bodalski J, Robak T (2004) Functional C3435T polymorphism of MDR1 gene: an impact on genetic susceptibility and clinical outcome of childhood acute lymphoblastic leukemia. Eur J Haematol 72: 314-321.

Kimchi-Sarfaty C, Oh JM, Kim IW, Sauna ZE, Calcagno AM, Ambudkar SV, Gottesman MM (2007) A 'silent' polymorphism in the MDR1 gene changes substrate specificity. Science 315: 525-528.

Krajinovic M, Labuda D, Mathonnet G, Labuda M, Moghrabi A, Champagne J, Sinnett D (2002) Polymorphisms in genes encoding drugs and xenobiotic metabolizing enzymes, DNA repair enzymes, and response to treatment of childhood acute lymphoblastic leukemia. Clin Cancer Res 8: 802-810.

Kroetz DL, Pauli-Magnus C, Hodges LM, Huang CC, Kawamoto M, Johns SJ, Stryke D, Ferrin TE, DeYoung J, Taylor T, Carlson EJ, Herskowitz I, Giacomini KM, Clark AG (2003) Sequence diversity and haplotype structure in the human ABCB1 (MDR1, multidrug resistance transporter) gene. Pharmacogenetics 13: 481-494.

Leschziner GD, Andrew T, Pirmohamed M, Johnson MR (2007) ABCB1 genotype and PGP expression, function and therapeutic drug response: a critical review and recommendations for future research. Pharmacogenomics J 7: 154-179.

Lin JH, Yamazaki M (2003) Role of P-glycoprotein in pharmacokinetics: clinical implications. Clin Pharmacokinet 42: 59-98.

McClure RF, Kaur P, Pagel E, Ouillette PD, Holtegaard CE, Treptow CL, Kurtin PJ (2006) Validation of immunoglobulin gene rearrangement detection by PCR using commercially available BIOMED-2 primers. Leukemia 20: 176-179.

McLeod HL, Krynetski EY, Relling MV, Evans WE (2000) Genetic polymorphism of thiopurine methyltransferase and its clinical relevance for childhood acute lymphoblastic leukemia. Leukemia 14: $567-572$.

Mega JL, Close SL, Wiviott SD, Shen L, Walker JR, Simon T, Antman EM, Braunwald E, Sabatine MS (2010) Genetic variants in ABCB1 and CYP2C19 and cardiovascular outcomes after treatment with clopidogrel and prasugrel in the TRITON-TIMI 38 trial: a pharmacogenetic analysis. Lancet 376: 1312-1319.

Mullighan CG, Su X, Zhang J, Radtke I, Phillips LA, Miller CB, Ma J, Liu W, Cheng C, Schulman BA, Harvey RC, Chen IM, Clifford RJ, Carroll WL, Reaman G, Bowman WP, Devidas M, Gerhard DS, Yang W, Relling MV, Shurtleff SA, Campana D, Borowitz MJ, Pui CH, Smith M, Hunger SP, Willman CL, Downing JR. Children's Oncology G (2009) Deletion of IKZF1 and prognosis in acute lymphoblastic leukemia. N Engl J Med 360: $470-480$.

Nachman J, Sather HN, Gaynon PS, Lukens JN, Wolff L, Trigg ME (1997) Augmented Berlin-Frankfurt-Munster therapy abrogates the adverse prognostic significance of slow early response to induction chemotherapy for children and adolescents with acute lymphoblastic leukemia and unfavorable presenting features: a report from the Children's Cancer Group. J Clin Oncol 15: 2222-2230.

Nakamura T, Sakaeda T, Horinouchi M, Tamura T, Aoyama N, Shirakawa T, Matsuo M, Kasuga M, Okumura K (2002) Effect of the mutation (C3435T) at exon 26 of the MDR1 gene on expression level of MDR1 messenger ribonucleic acid in duodenal enterocytes of healthy Japanese subjects. Clin Pharmacol Ther 71: 297-303.

Pawlik A, Baskiewicz-Masiuk M, Machalinski B, Kurzawski M, GawronskaSzklarz B (2005) Involvement of C3435T and G2677T multidrug resistance gene polymorphisms in release of cytokines from peripheral blood mononuclear cells treated with methotrexate and dexamethasone. Eur J Pharmacol 528: 27-36. 
Pongers-Willemse MJ, Seriu T, Stolz F, d'Aniello E, Gameiro P, Pisa P, Gonzalez M, Bartram CR, Panzer-Grumayer ER, Biondi A, San Miguel JF, van Dongen JJ (1999) Primers and protocols for standardized detection of minimal residual disease in acute lymphoblastic leukemia using immunoglobulin and T cell receptor gene rearrangements and TAL1 deletions as PCR targets: report of the BIOMED-1 CONCERTED ACTION: investigation of minimal residual disease in acute leukemia. Leukemia 13: 110-118.

Pui CH, Campana D, Pei D, Bowman WP, Sandlund JT, Kaste SC, Ribeiro RC, Rubnitz JE, Raimondi SC, Onciu M, Coustan-Smith E, Kun LE, Jeha S, Cheng C, Howard SC, Simmons V, Bayles A, Metzger ML, Boyett JM, Leung W, Handgretinger R, Downing JR, Evans WE, Relling MV (2009) Treating childhood acute lymphoblastic leukemia without cranial irradiation. N Engl J Med 360: 2730-2741.

Pui CH, Carroll WL, Meshinchi S, Arceci RJ (2011) Biology, risk stratification, and therapy of pediatric acute leukemias: an update. J Clin Oncol 29: 551-565.

Rahgozar S, Moafi A, Abedi M, Entezar EGM, Moshtaghian J, Ghaedi K, Esmailie A, Montazeri M (2014) mRNA expression profile of multidrug resistant genes in acute lymphoblastic leukemia of children, a prognostic value for ABCA3 and ABCA2. Cancer Biol Ther 15: 35-41.

Relling MV, Hancock ML, Boyett JM, Pui CH, Evans WE (1999) Prognostic importance of 6-mercaptopurine dose intensity in acute lymphoblastic leukemia. Blood 93: 2817-2823.

Rocha JC, Cheng C, Liu W, Kishi S, Das S, Cook EH, Sandlund JT, Rubnitz J, Ribeiro R, Campana D, Pui CH, Evans WE, Relling MV (2005) Pharmacogenetics of outcome in children with acute lymphoblastic leukemia. Blood 105: 4752-4758.

Sauna ZE, Kimchi-Sarfaty C (2011) Understanding the contribution of synonymous mutations to human disease. Nat Rev Genet 12: 683-691.

Schultz KR, Pullen DJ, Sather HN, Shuster JJ, Devidas M, Borowitz MJ, Carroll AJ, Heerema NA, Rubnitz JE, Loh ML, Raetz EA, Winick NJ, Hunger SP, Carroll WL, Gaynon PS, Camitta BM (2007) Risk- and response-based classification of childhood B-precursor acute lymphoblastic leukemia: a combined analysis of prognostic markers from the Pediatric Oncology Group (POG) and Children's Cancer Group (CCG). Blood 109: 926-935.

Scrucca L, Santucci A, Aversa F (2007) Competing risk analysis using R: an easy guide for clinicians. Bone Marrow Transplant 40: 381-387.

Scrucca L, Santucci A, Aversa F (2010) Regression modeling of competing risk using R: an in depth guide for clinicians. Bone Marrow Transplant 45: $1388-1395$.

Simon T, Verstuyft C, Mary-Krause M, Quteineh L, Drouet E, Meneveau N, Steg PG, Ferrieres J, Danchin N, Becquemont L (2009) Genetic determinants of response to clopidogrel and cardiovascular events. N Engl J Med 360: 363-375.

Stanulla M, Schaeffeler E, Flohr T, Cario G, Schrauder A, Zimmermann M, Welte K, Ludwig WD, Bartram CR, Zanger UM, Eichelbaum M, Schrappe M, Schwab M (2005a) Thiopurine methyltransferase (TPMT) genotype and early treatment response to mercaptopurine in childhood acute lymphoblastic leukemia. JAMA 293: 1485-1489.
Stanulla M, Schaffeler E, Arens S, Rathmann A, Schrauder A, Welte K, Eichelbaum M, Zanger UM, Schrappe M, Schwab M (2005b) GSTP1 and MDR1 genotypes and central nervous system relapse in childhood acute lymphoblastic leukemia. Int J Hematol 81: 39-44.

van der Velden VH, de Bie M, van Wering ER, van Dongen JJ (2006) Immunoglobulin light chain gene rearrangements in precursor-B-acute lymphoblastic leukemia: characteristics and applicability for the detection of minimal residual disease. Haematologica 91: 679-682.

Waldmann TA, Lugli E, Roederer M, Perera LP, Smedley JV, Macallister RP, Goldman CK, Bryant BR, Decker JM, Fleisher TA, Lane HC, Sneller MC, Kurlander RJ, Kleiner DE, Pletcher JM, Figg WD, Yovandich JL, Creekmore SP (2011) Safety (toxicity), pharmacokinetics, immunogenicity, and impact on elements of the normal immune system of recombinant human IL-15 in rhesus macaques. Blood 117: 4787-4795.

Wolf SJ, Bachtiar M, Wang J, Sim TS, Chong SS, Lee CG (2011) An update on $\mathrm{ABCB} 1$ pharmacogenetics: insights from a 3D model into the location and evolutionary conservation of residues corresponding to SNPs associated with drug pharmacokinetics. Pharmacogenomics J 11: 315-325.

Xu H, Cheng C, Devidas M, Pei D, Fan Y, Yang W, Neale G, Scheet P, Burchard EG, Torgerson DG, Eng C, Dean M, Antillon F, Winick NJ, Martin PL, Willman CL, Camitta BM, Reaman GH, Carroll WL, Loh M, Evans WE, Pui CH, Hunger SP, Relling MV, Yang JJ (2012) ARID5B genetic polymorphisms contribute to racial disparities in the incidence and treatment outcome of childhood acute lymphoblastic leukemia. J Clin Oncol 30: 751-757.

Yang JJ, Cheng C, Devidas M, Cao X, Campana D, Yang W, Fan Y, Neale G, Cox N, Scheet P, Borowitz MJ, Winick NJ, Martin PL, Bowman WP, Camitta B, Reaman GH, Carroll WL, Willman CL, Hunger SP, Evans WE, Pui CH, Loh M, Relling MV (2012) Genome-wide association study identifies germline polymorphisms associated with relapse of childhood acute lymphoblastic leukemia. Blood 120: 4197-4204.

Yang JJ, Cheng C, Yang W, Pei D, Cao X, Fan Y, Pounds SB, Neale G, Trevino LR, French D, Campana D, Downing JR, Evans WE, Pui CH, Devidas M, Bowman WP, Camitta BM, Willman CL, Davies SM, Borowitz MJ, Carroll WL, Hunger SP, Relling MV (2009) Genome-wide interrogation of germline genetic variation associated with treatment response in childhood acute lymphoblastic leukemia. JAMA 301: 393-403.

Yeoh AE, Ariffin H, Chai EL, Kwok CS, Chan YH, Ponnudurai K, Campana D, Tan PL, Chan MY, Kham SK, Chong LA, Tan AM, Lin HP, Quah TC (2012) Minimal residual disease-guided treatment deintensification for children with acute lymphoblastic leukemia: results from the malaysia-singapore acute lymphoblastic leukemia 2003 study. J Clin Oncol 30: 2384-2392.

Yoshikai Y, Nishimura H (2000) The role of interleukin 15 in mounting an immune response against microbial infections. Microbes Infect 2: 381-389.

This work is published under the standard license to publish agreement. After 12 months the work will become freely available and the license terms will switch to a Creative Commons AttributionNonCommercial-Share Alike 3.0 Unported License.

Supplementary Information accompanies this paper on British Journal of Cancer website (http://www.nature.com/bjc) 